\title{
Making Sense of the Unknown: A Narrative Analysis of COVID-19 Stories as Told by WSU Research Students
}

\author{
Alicia van der Spuy ${ }^{* 1} \&$ Lakshmi Jayakrishnan ${ }^{1}$ \\ *Corresponding Author: avdspuy@wsu.ac.za \\ 1. Walter Sisulu University, South Africa \\ Received : 2021-06-14 \\ Revised : 2021-07-27 \\ Accepted : 2021-08-26
}

$10.46303 /$ ressat.2021.18

\begin{abstract}
How to cite this paper: van der Spuy, A. \& Jayakrishnan, L. (2021). Making Sense of the Unknown: A Narrative Analysis of COVID-19 Stories as Told by WSU Research StudentsResearch in Social Sciences and Technology, 6(2), 183-198. https://doi.org/10.46303/ressat.2021.18

\begin{abstract}
Storytelling is an important tool through which to make sense of life experiences. Stories can be classified as personal narratives, historical documentaries and those that inform the viewer about a specific concept or practice. These narratives can be used to promote discussion about current issues in the world. Storytelling can thus be seen as an effective learning tool for students by providing a strong foundation in "Twenty First Century Literacy" skills as well as advancing emotional intelligence and social learning. This project used storytelling to gather information regarding people's encounters with COVID-19 and lockdown, with specific focus on the Eastern Cape of South Africa. Employing a content analysis methodology, it attempts to analyze responses to narrative inquiry interviews about the COVID-19 pandemic as conducted by students, as part of their introduction to the methodology of research. These responses were used to generalize findings, as well as to look at individual reactions that could bring light to, and make sense of the human experience of the pandemic within an educational context. Both negative and positive experiences were related by interviewees and students.
\end{abstract}

Keywords: content analysis, COVID-19, change, narrative inquiry, storytelling

\section{Introduction}

The arrival of the COVID-19 pandemic on South African shores in March 2020 (National Institute for Communicable Diseases, 2020), and the Level 5 lockdown that started on 26 March 2020 (South African News Agency, 2020) forced teachers and lecturers alike to rethink the way they were teaching (Williams et al., 2021).

For centuries, the focus in higher education has been on teaching. Jansen (2004, in Mpungose, 2020) states that traditional face-to-face learning excludes students' experiences, as the lecturer deposits knowledge for students in a physical classroom using traditional methods (lecturer-centred) and resources. However, there is no access to these physical classrooms when faced with challenges such as student protests and pandemics. COVID-19 and the shift 
to digitalization have turned the spotlight on learning. Existing literature (Carrillo \& Flores, 2020; Mpungose, 2020; Wimpenny et al., 2020) refers to the myriad challenges faced by academic staff who, in the wake of COVID-19, have had to shift from the traditional classroom approach to technology-driven methods. The pressure to offer learners customized solutions has reached the higher education arena at great cost to the wellbeing of academic staff who are left floundering in the tsunami-like waters of the pandemic. In fact, as Tarman (2020:) stated, academics are in a "permanent state of transformation".

Carrillo and Flores (2020) point to 'emergency remote teaching' or 'emergency eLearning' and to difficulties associated with poor online teaching infrastructure, inexperience of teachers, the information gap with regard to information and resource access for all students, the complex environment at home, lack of mentoring and support and the different nature of the roles and competences required to teach effectively in the online higher education environment (Carrillo \& Flores, 2020; Wimpenny et al., 2020).

As lecturers attempting to teach students basic research skills, we had to redesign our course to fit the restrictions of the lockdown, whilst instilling the principles of ethical research in our students. The topic of research thus became the COVID-19 pandemic lockdown itself, and students were expected to interview members of their household. Not only did they have to ask their immediate family members to relate their experiences of the lockdown, but they also had to ask them for the story of their lives, in keeping with the dictates of narrative analysis (Clandinin, 2013).

What followed from this project was a narrative of personal experiences of the people of the Eastern Cape Province of South Africa regarding COVID-19 and the lockdown.

\section{Purpose of the study}

On the evening of 15 March 2020, South African President Cyril Ramaphosa announced that all schools would shut with effect from 18 March, which prompted several universities to announce a suspension of their academic programs. A statement by the Ministry of Higher Education, Science and Technology on 18 March pronounced that all universities and postschool institutions were to close for early recess immediately. University vice-chancellors as well as other stakeholders met to discuss the implications and decided to halt teaching and learning at all higher education institutions. Walter Sisulu University (WSU) in the Eastern Cape also announced precautionary measures in an online statement.

Due to the lockdown, universities found it challenging to offer their course material online. Academics had to rework and adapt the curriculum for emergency remote teaching with practically little to no training, in a short timeframe. This came with several challenges for disadvantaged universities like WSU which experienced difficulties in making the transition to emergency remote teaching, leading to a delay in the resumption of academic activities.

The COVID-19 pandemic unquestionably showed up the inequalities in the higher education institutions in South Africa. As lecturers teaching the Research Project module in the Advanced Diploma: Public Relations and the National Diploma: Journalism program at WSU, modules which required regular contact sessions with students, we were impacted, along with the students, in the sudden shift to the online delivery of programs. It thus became imperative to 
van der Spuy, A. \& Jayakrishnan, L. Making Sense of the Unknown:

A Narrative Analysis of COVID-19 Stories as Told by WSU Research Students

use the module to investigate and make sense of the pandemic experience. The aim was to reveal the lived experiences of the lockdown, with specific focus on the people of the Eastern Cape. For this purpose, the focus was on the positive and negative impact of the pandemic.

As the grounding for this study is narrative inquiry, students were not expected to approach the research with an end goal in mind, but to enter into a relationship with their interviewees in order to find in-depth information. However, as lecturers, we focused on the experiences of Eastern Cape residents during the so-called "hard" lockdown (levels 5 and 4) - whether there were positive as well as negative experiences, and, lastly, how students from mostly disadvantaged backgrounds experienced their online learning.

\section{Literature Review}

Both narrative inquiry and content analysis form the basis of our study: firstly, as the theoretical basis for the students' work and secondly, as the method of analysis for our research. It is therefore prudent to discuss this as the foundations of the study.

Humans tell stories about their lives and those of others in order to make sense of their experience of the world (Clandinin, Cave, \& Berendonk, 2017). We interpret our experiences through our narratives in order to make them meaningful (Clandinin, 2013). We can, therefore, be considered as characters in our own stories and those of others (Connelly \& Clandinin, 1990). Narrative inquiry can be seen as "a way of understanding and inquiring into" the experiences of others and yourself (Clandinin, 2013); expressly, it is a way to think about human experience.

Influenced by John Dewey's two criteria of experience, namely interaction and continuity, Clandinin and Connelly (2000) developed their theory on narrative inquiry as both a phenomenon to be studied and a method that informs the inquiry. According to this understanding, narrative is the experience studied by narrative inquirers (Clandinin, 2006) and must therefore not only be understood as a personal experience, but also within a specific context. This context encompasses the time (or 'continuity'), the place ('situation') and the social environment (or 'interaction'), not only of when the experience took place, but when it is told (Clandinin, 2013). Clandinin refers to this context as the 'three-dimensional narrative inquiry space' (2006, p. 47). The study of narrative, therefore, has to do with examining how humans experience the world (Connelly \& Clandinin, 1990) within a certain framework which may be constantly changing. This implies that the researcher working with narrative inquiry must be flexible in order to cope with the possible changes in the direction of the research (Gilstein, 2020).

The researcher engaged in narrative inquiry must be aware that the story is continuing even when it is being told (Connelly \& Clandinin, 1990). This was especially true for our research on COVID-19 experiences as, at the time of writing, the pandemic and people's lived experiences of it were still going on. There must also be an awareness of the subjectivity of these narratives (Gilstein, 2020), which may be difficult for other researchers to understand.

Clandinin (2013) postulates that a mere analysis of collected stories is not valid narrative analysis. For narrative analysis to be true, not only must the researcher's report form part of the narrative, but the researcher has to live the narrative. However, we believe that any 
van der Spuy, A. \& Jayakrishnan, L. Making Sense of the Unknown:

A Narrative Analysis of COVID-19 Stories as Told by WSU Research Students

reporting on stories is adding to the narrative and that the value in this reporting lies in the fact that a voice is given to individuals who may not have been heard before. As Gilstein (2020) states, individual experience is important in narrative analysis and this methodology allows the unique voice of individual experience to be heard - something that may not have been heard before. Our paper ties in with this sentiment, as the voices of the people of the Eastern Cape are heard through this study.

Content analysis was used to analyze the texts produced by the students. Krippendorff (1989, p. 403) defines content analysis as "a research technique for making replicable and valid inferences from data to their context". Within a communication context, this methodology can be applied to anything that can provide enough data, whether it is a newspaper publication, literary text or open-ended interviews, such as the ones that we used in this study. We used the texts that the students had produced as their research in order to perform a content analysis on the information provided, with the goal of discovering how people of the Eastern Cape province experienced the lockdown and its regulations.

Hsieh and Shannon (2005) further described the different techniques used in content analysis as the conventional, directed and summative techniques. According to them, the specific method is dependent on the purpose of the study. If your aim is to describe the phenomenon, as in our study, the conventional approach will be used. The advantage of this method is that information is obtained directly from the participants, and the researchers cannot have any preconceived ideas as to what they will discover (Hsieh \& Shannon, 2005).

Content analysis can be used to study media content, gather intelligence, or to research social sciences and literature (Hsieh \& Shannon, 2005). In the case of this paper, the information provided by the research students became the text data that could be studied.

\section{Methodology}

Subsequent to the closure of the university and amid plans to save the academic year, we, as lecturers in charge of the Research Project module for our respective programs (Journalism and Public Relations) in the Department of Corporate Communication and Marketing at WSU, had to think of a way in which the students could still conduct a research study within the limitations of the lockdown. We were forced to think about what model we could use to deliver the module and how the students' individual projects could best be executed. These deliberations assisted in determining the aim and methodology of the study. The module was offered online, social media student groups were formed and information was disseminated. Microsoft Teams and WhatsApp were used for supervisory meetings and sessions to follow up on progress and give guidance.

\section{Design}

The aim of the study was to reveal the lived experiences of the lockdown, with specific focus on the people of the Eastern Cape. Individual stories from the community were collected for this purpose with a narrative inquiry approach. The researcher then became the interpreter of these stories. 
van der Spuy, A. \& Jayakrishnan, L. Making Sense of the Unknown:

A Narrative Analysis of COVID-19 Stories as Told by WSU Research Students

Students had approximately six months in which to complete their interviews and papers. As already stated, their transcripts were used as texts for our analysis. The approach was, therefore, qualitative.

\section{Participants}

The experiences of the people of the Eastern Cape during the lockdown were explored using interviews. Due to lockdown restrictions, convenience sampling (student researchers contacted family, friends, neighbours and people who were accessible to them) was used.

A total of 88 students submitted their projects. Forty-four of these students were from the National Diploma: Journalism, and thirty-nine were from the Advanced Diploma in Public Relations Management. Interviews that were not in line with the brief, were discarded. This meant that interviews with interviewees from provinces other than the Eastern Cape, or interviews that did not refer to COVID-19 lockdown experiences, were excluded from this paper. 167 useful interviews were collected, with 100 female respondents and 67 male respondents when using a binary definition of gender.

Respondents came from many areas of the Eastern Cape, including but not limited to, Mdantsane, East London, Gqeberha, Mount Frere, Lusikisiki and Mthatha. Ages ranged from sixteen to 84, and all participants gave informed consent for their information to be used in a research study. The interviewees were from all walks of life as reflected in their occupations, for example, teachers, nurses, business owners, students and the unemployed. All of the interviewees were given a number to maintain anonymity.

Out of 167 respondents, we identified 82 who commented on family life, 52 who commented on community life, 92 who remarked on work life and 50 who mentioned student life.

\section{Instruments}

Open-ended interview questions were asked of the participants by the student researchers to explore their lived experiences of the pandemic. It is worth mentioning that the students were novice researchers and the questions developed were based on the positive and negative impact of COVID-19. The students' interpretations and subsequent reports were used as information, instead of the actual interview transcripts.

\section{Data collection procedure}

Student researchers were instructed to collect the stories of three people known to them. In some cases, they had face-to-face interviews with family members living at home with them during lockdown; in other cases, they made use of telephonic interviews or social media messengers, such as WhatsApp. One student researcher conducted three interviews and held a focus group discussion of six university students to explore their experiences of emergency remote teaching.

The interviews were conducted physically where possible, telephonically and through online platforms such as social media and messengers. 
van der Spuy, A. \& Jayakrishnan, L. Making Sense of the Unknown:

A Narrative Analysis of COVID-19 Stories as Told by WSU Research Students

\section{Data analysis}

The data was analyzed using a conventional content analysis approach (Hsieh \& Shannon, 2005), a qualitative methodology closely related to narrative inquiry (Clandinin, 2013). As such, this study is not a true narrative inquiry study as per Clandinin's definition. Instead, we used "narrative as content analysis" (Clandinin, 2013) in order to analyze the data.

In this process we therefore had used Hsieh and Shannon's (2005) five steps of data analysis, namely; converting text into narrative, determining units of analysis and themes, making rules for the coding system, applying the coding system to all narrative data and revise if not proper, and verifying and selecting final data.

This meant that the texts produced by the students were used as our data. We organized key thoughts into categories and identified common themes amongst the stories, using thematic coding. The final broad categories were labelled 'negatives' and 'positives', and each category was divided into sub-categories, namely personal life, community life, work life and student life. These sub-categories appeared in both the main categories. The characteristics of the messages were therefore identified and coded according to themes (Stemler, 2000). We have also sought to establish trustworthiness and validity of the study by explaining in detail the method, design, data collection and data analysis processes.

\section{Findings}

The findings are presented in terms of themes identified during our analysis, namely the broad categories of positive and negative experiences, family life, community life, work life and student life.

\section{Family Life}

The financial impact on families due to job losses, not qualifying for the pandemic relief grant, salary deductions and being put on unpaid leave was alarming. Respondents also discussed the emotional impact and trauma of losing family members to COVID-19, the anxiety of losing family, having to stay away from family and the fear of infecting relatives with the virus.

Many respondents commented on their fear for their families and children. Respondent 2 (female, 50) said that she was fearful for her family and herself. Respondent 8 (male, 23) stated that he was worried about his elderly mother, as she was at risk of contracting the virus. This was similar to respondent 97's (female, 44) concerns, namely that her 73-year old mother would become sick. Respondent 9, a nineteen-year-old female, lived with her grandmother and worried that she would infect her. Respondent 120 (female, 27) also discussed how she complied with the pandemic rules and regulations and stayed home to protect her grandmother. Mothers with young babies, such as respondent 40 (female, nap [no age provided]), had problems taking their children for their vaccinations and this concerned them. Those working on the frontline, such as nurses and community workers, were anxious that they would contract the virus and infect their families. A carer in an old age home (respondent 50, female, 53) revealed that she was terrified that she would infect her family at home or that she would infect the elderly at work. 
van der Spuy, A. \& Jayakrishnan, L. Making Sense of the Unknown:

A Narrative Analysis of COVID-19 Stories as Told by WSU Research Students

Job losses within the family brought insecurity and hardship. Respondent 99 (male, 35) said that family members lost their jobs and he was under a lot of pressure to provide for them, too. Respondent 22 (male, 34) stated that his aunt lost her job and that he was then responsible for her and his cousins. Respondent 12 (female, 63) also said that her son lost his job and that he struggled to find a new one due to the lockdown. Respondent 4 (male, 24) told of how his father lost his job.

Interviewees who did not live at home, found it difficult that they could not visit their loved ones or that their loved ones could not visit them due to the restriction on travel across province borders. Respondent 8 (male, 23) was one of those who could not see his loved ones, as he was away from home. This caused "panic", especially as he was also worried about his mother, a diabetes patient. A 63-year-old woman (Respondent 11) found it difficult that her children could not visit, because they did not live in the Eastern Cape. This was similar to respondent 37's (male, 72) experience. Respondent 105 (male, 36) also found it difficult that he could not visit his family. Respondent 121 (male, 42) mentioned how the sudden international travel restrictions separated him and his wife from their children in Zimbabwe.

Whilst the South African government had set up a fund to pay out the special COVID-19 Social Relief of Distress (SRD) grant (South African Government, 2021), many interviewees complained that they did not receive the grant. They did not indicate whether they had applied online, as applications were only accepted via the internet. The beneficiaries of the grant were grateful, as it extended the grants they were already receiving, or as it helped with essentials. Respondent 21 (female, 53) divulged how they had previously relied on her daughter's internship stipend, and currently had to rely on the social relief fund for survival. Respondent 39 (female, 40) had four children at home and said that she relied on the child grant. She also indicated that her oldest son dropped out of school; an indication that the cycle of poverty may continue. Respondent 49 (female, 55) said that she lived off the social grant of two elderly people, but she was fearful when she had to go to town to withdraw money, as she had to make use of a minibus taxi to get to town. Respondent 61 (male, 61) said that the increase in money helped him greatly. Previously he had to borrow money from neighbors in order to survive until the next grant pay day, but with the extra money, he did not need to do that. However, people who had to also take care of others, such as Respondent 92 (female, 28) found it difficult to survive on the small grant.

Respondent 122 (male, 29) experienced salary deductions and being unpaid for a few months while having to isolate with his family and take care of his wife who was recovering from COVID19. Nearly all COVID-19 survivors mentioned the trauma of being ill while at the same time being terrified of spreading the virus to close family members. Respondent 123 (female, 30) survived COVID-19 only to lose her grandparents to the virus. Respondents also described the pain of not being able to say goodbye to loved ones due to lockdown regulations and this seemed particularly important to the elderly, like Respondent 141 (female, 74).

Respondents also seemed to find living with family in lockdown, taxing. Grandparents like Respondent 141 found the grandchildren uncontrollable and noisy, whereas the younger generation found it difficult to attend online lessons in a noisy environment and were expected to do domestic chores thus wasting precious study time (Respondents 154 and 159 nap). 
van der Spuy, A. \& Jayakrishnan, L. Making Sense of the Unknown:

A Narrative Analysis of COVID-19 Stories as Told by WSU Research Students

The positive side of the lockdown in terms of family life was, for many, that they had the opportunity to spend time with their families. Respondent 111 (female, 50) said that she could spend "bonding time" with her family. This was the same for respondents 1 (female, 39), 22 (female, 21), 54 (female, 50), 67 (female, 17), 70 (male, 31) and 72 (male, 16). Respondent 72 explained that he was forced to spend more time with his mother and his niece, as his father and brother both worked in Johannesburg. The advantage of this for him was that he got to know and understand them better, and vice versa. Respondent 67 said that she spent more time with her family, especially her parents, as they always were at work previously.

\section{Community Life}

Many respondents commented on the fact that they could not attend funerals. This had to do with family duties that could not be performed (respondent 1, female, 39), or the fact that a dignified send-off could not be arranged (respondent 5, female, 39). This was especially painful to respondent 45 (female, 37) who lost her mother during the lockdown. She said that her mother was well-known in the community, but that they could not honor her mother in the way that she deserved. The fact that they could not pay a "final tribute" (respondent 6 , female, 62) or pay their last respects (respondent 12, female, 63; respondent 18, female, 54; respondent 19, female, 34; respondent 101, male, 64; respondent 102, female, 25) featured strongly. Some of the respondents could not attend the funeral of a close family member due to the travel restrictions that did not allow for travel between provinces without a valid permit. Respondent 37 (male, 72) could not attend the funeral of his sister in Johannesburg. For some, like respondent 58 (female, 33) it was difficult to bury her mother, as she passed away in another province. She said that she could not get a permit to travel, as, when she went to apply, the people who could authorize the permit were not available, or there were technical issues. Respondent 43 discussed not being able to attend the funerals of his colleagues (male, 25). He did not indicate the reason, which might possibly be linked to COVID-19 related restrictions. Some respondents felt that they could not be there for the community when there was a funeral nor show their support (respondent 54, female, 50; respondent 70, male, 31; respondent 76, female, 61). From the many responses received on this issue - the most of any topic under the category community life - it is clear that the regulations around funeral attendance was deeply felt within the community.

Another topic that came up under this category, was that of church attendance. Although only four respondents brought this up (respondent 6, female, 62; respondent 41, female, nap; respondent 51, female, 61; respondent 54, female, 50). This may be because of the support that they felt they missed, or the sense of community experienced at church.

Furthermore, some respondents commented on their lack of a social life. Respondent 3 (female, 16 ) said that, although it was good to spend time with family, she was a social person but could not see her friends. Number 60 (female, 26) said that her social life was badly affected, while respondent 70 (male, 31) indicated that he loved playing pool and going to swimming pools and the beach, but he could not do any of these activities. Respondent 78 (male,22) was a keen football (soccer) player, but could not participate in the sport during the lockdown. They were stopped by the police while attempting to play a match. Respondent 80 (male, 79) also said that he could not visit his friends. 
Traditions and customs were also brought up. Respondent 10 (female, 36) said they could not practice tradition, but it was unclear which traditions she referred to. Respondent 26 (male, 28) stated that initiation could not continue, as well as other customs and traditions. For respondent 71 (male, 19) the lockdown meant that the rituals around his initiation into manhood could not be completed. The shops were closed and he could not start wearing what he termed "normal" clothes, as the shops where he was supposed to buy new clothes were closed. Liquor stores were also closed, which meant that he could not buy the liquor needed to complete the transition.

Many respondents were fearful to come into contact with others (respondent 11, female, 63; respondent 18 , female, 54 ; respondent 26 , male, 28 ). They commented on a fear of neighbors, of going to town to buy groceries and of long queues. Two interviewees (respondent 31, male, 32; respondent 33, male, 35) commented on the lack of enforcement of the lockdown rules. They said the ban on alcohol and the curfew were not effective, as there was nobody to enforce these. Respondent 31 (male, 32) worked as a journalist during this time. He was also concerned about people's behavior and attitudes, as well as the lack of monitoring. Respondent 141 (female, 74) mentioned her fear of going out due to her vulnerable age and her forgetfulness to wear a mask. She mentioned how she would always urge other members of the community to wear masks and be safe by following all precautions and drinking certain tonics. She missed going to church where she got to interact socially with others and not being able to attend funerals.

One respondent (no. 34, male, 35) mentioned the negative effects of the strict lockdown on the LGBTQI community. He said that those who needed hormone treatment, could not access their hormones. Others, who needed pre-exposure prophylaxes or antiretroviral medication, could also not travel to where they could obtain their drugs.

Respondent 115 (female, 35), though not directly affected, discovered that she wanted to comfort people who'd been distressed by the pandemic and began writing a motivational blog. A number of respondents $(117,118,119,135,136,137,138,141,152$, nap) all urged the importance of exercising caution and following the pandemic rules and regulations. Many suggestions were also related to the government's handling of the pandemic and although many were satisfied with the government's stance and grateful for the relief grant, they suggested that government focus on improving the vaccine drive and discrediting false information on social media. Respondent 117 (female, 27) asserted that seeing public officials getting the vaccine would induce the public into getting them. Respondents 118 (female, 26), 119 (male, 17) and 138 (female, nap) suggested free supply of masks and sanitizers to the poor, closing borders to international travelers, closing of churches, which people consider a place of safety thus getting infected; and closing "unhygienic" businesses such as hair salons and vegetable vendors. Respondent 138 was of the view that the country should go into lockdown.

Respondents 121 (male, 42) and 122 (male, 29) made comparisons with other pandemics such as cholera, HIV/AIDS and listeriosis, claiming that the COVID-19 pandemic had a global reach with a higher rate of deaths. Respondent 117 (female, 27) referred to the lack of visibility of law enforcement officials during lockdown. People were losing jobs and not qualifying for the relief grant, and lockdown rules were not being enforced in townships where homes did not 
van der Spuy, A. \& Jayakrishnan, L. Making Sense of the Unknown:

A Narrative Analysis of COVID-19 Stories as Told by WSU Research Students

have enough rooms for social distancing. This led to a sense of frustration and lack of trust in the government.

According to the respondents, the only positives to come from the lockdown with regards to their community, were fewer drunk people (respondent 92, male, 52), less crime and a decrease in road accidents (respondent 105, female, 58). Respondent 30 (female, 55), a police officer, said that patrols and roadblocks helped people, and respondent 105 (female, 58) said that the ban on alcohol was a good thing.

\section{Work Life}

The responses around the category "work life" were overwhelmingly negative. Topics under this sub-category were essential workers, business owners - established and new, so-called "side hustles", job losses and unemployment.

Work life was described as a source of stress, fear and anxiety as many respondents suffered job losses (Respondents 141, 143, nap), salary deductions (Respondents 121, 122, nap), unpaid leave (Respondent 122, nap) or worried about their future prospects in getting a job (Respondents 120,161, 165, nap). Due to the lockdown, some respondents were unable to go to work (Respondent 118, nap), witnessed their company sales decrease or clients withdrawing from contracts and lack of funds (Respondents 132, 134, nap), and family members losing jobs (Respondents 117, 147, 150, nap). Business owners like Respondent 158 (male, nap) and Respondent 162 (male, 27) suffered from a loss of income and had to send employees home. They acknowledged anxiety about the business and the future. Respondent 166 (male, 33), a professional boxer, could not travel to matches due to lockdown restrictions nor could he offer boxing lessons in the community.

Essential workers commented on a number of issues, for example shift work, training, shift work and personal protective equipment (PPE). Respondent 19 (female, 34) worked in a community health care center. She said that "extreme changes" were made in order to ensure the safety of the staff and patients. They also had to work in shifts in order to minimize the number of people at work. Respondent 30 (female, 55), a police officer, also said that they had to work shifts. At one stage, the station was closed due to COVID-19 and they had to work rotating shifts in order to comply with social distancing rules. Respondent 63 (male, 24), a nurse, disclosed that they were not provided with any training on prevention and management of the disease. They also did not get PPE. They lost colleagues, but received no psychological help to cope with the situation. Another community health worker, respondent 69 (female, 44), said that the conditions under which they had to work, was extremely stressful. They did not have PPE and had to use cloth masks. This led to anxiety, depression and stress. Respondent 64 (female, 27) was a speech therapist. She admitted to being terrified due to the risk of infection, as she was doing her training at a provincial hospital.

Business owners were negatively affected. Respondent 13 (male, 55) was a crop farmer. He could not purchase the necessary seeds to plant and said that it will take a long time to recoup his losses. This was also true for respondent 25 (male, 52), who worked as a builder. He could not continue to work, as he was unable to buy the necessary supplies. Respondent 37 (male, 72) used to sell alcohol, but due to the ban on alcohol sales as well as the closure of his providers, he could not continue to do so. Respondent 59 (female, 47) said that she was 
van der Spuy, A. \& Jayakrishnan, L. Making Sense of the Unknown:

A Narrative Analysis of COVID-19 Stories as Told by WSU Research Students

tendering for government, but she lost money and had to rely on rental income to survive. Similarly, respondent 85 (male, 31) could not purchase the material he needed for his job as a carpenter.

New business owners had other issues, as they had been unable to build up a buffer against unforeseen circumstances. Respondent 77 (female, 37) had just started a small catering business, but had to close it. She said that even after the initial lockdown restrictions were lifted, there were fewer people around and she had less business. Respondent 7 (male, 21) registered a new public relations company in 2020, but the promotion of the company had to be put on hold. She had applied for funding from government, but received nothing. Similarly, respondent 56 (female, 24) had wanted to start her own business and applied for funding, but could not continue due to the lockdown. Respondent 78 (female, 60) started her own business distributing soap. She said it had started to boom before the lockdown, but that COVID-19 had "delayed" her business.

Many people relied on what they called "side hustles" to make ends meet. This means that they will have a specific job, but they will do other things, such as sell cosmetic products, to get by. Respondent 8 (male, 23), a student, said his finances were badly affected, as he could not continue with his side hustles. Those looking for "piece jobs", or day jobs paying a daily wage, were also badly influenced. Respondent 28 (male, 55) said that he could not seek piece jobs, which would have involved travel. He often had nothing to eat, but his community helped and he also received food parcels. Respondent 109 (male, 40) admitted to an illegal side hustle, in which he gave loans to others in his community and then charged interest. It is unclear whether he knew that this was illegal, as he was not a registered credit provider.

Interviewees spoke of job losses caused by the lockdown, whether their own jobs (respondent 33, male, 31; respondent 36, female, 24; respondent 39, female, 40; respondent 54, female, 50 ) or those of others (respondent 89 , female, age unknown). Some said that they could not look for a job due to the lockdown. Companies were retrenching instead of hiring (respondent 16, male, 27). This was of particular concern to students in their final year of study, as they feared that they would not obtain employment despite being qualified (respondent 103, male, nap; respondent 99, female, 23).

Some interviewees told how their hours were cut and that their income decreased because of this. Respondent 36 (female, 24) said she was a temporary worker. She had to work shorter hours and received a lower pay. She then obtained a permanent position at a hospital, but she was afraid of taking it, as she feared she may contract COVID-19. She was then unemployed for two months before she was rehired. Respondent 48 (male, 55) was a taxi driver, but due to government restrictions, they could initially only load $30 \%$ of capacity. This decreased his income, especially as he was also expected to provide passengers with sanitizers. He had a small shop at home, but his customers were fewer than before. Respondent 52 (male, 31), another taxi driver, also commented on the fact that he was not allowed to carry a full load. Respondent 90 (male, 29), also a taxi driver, said that his job was safe, meaning that he knew he would not lose it, but his income was lower. Interviewee 82 (female, 47) explained that her hours and days at the retail shop where she worked, were shortened. She was without an income for two months and the Unemployment Insurance Fund took a long time to pay out. Respondent 88 
worked as a cleaner during the lockdown period. She said that they were not paid their full salaries, but that they could not complain, as nobody was in the office due to lockdown regulations. Respondent 58 (female, 33) worked as a receptionist, but received only half her salary.

Some of the interviewees were teachers. Respondent 35 (female, 24) said that they had issues with learners not attending classes, as they were scared of contracting the virus at school. They also had to offer extra classes to the learners. Respondent 73 (female, 28) said that the learners were badly affected, as they were basically left alone to cope with the work. A school principal (respondent 107, male, 41) said that the learners were behind on the school syllabus and that they faced a challenging situation. The Grade 12 students were lagging behind and this would have an impact on their record exams, which would give them entrance to universities and colleges.

Other experiences were more singular, as only one or two interviewees referred to this topic. Respondent 14 (male,71) was a bishop in a rural area. According to him, COVID-19 ruined the plans of the congregation. He did not elaborate on these plans, however. Respondent 97 (female, 45) ran a non-governmental organization (NGO) that took care of the elderly in the community. She could not continue with her work, as her funding was stopped. Another respondent (Respondent 70, male, 31) worked at a garage and had to continue working during the lockdown. Public transport was an issue for him, as he worked shifts and transport was not always available when he needed it. He sometimes had to walk to and from work. He said that the police would sometimes give him a lift home, especially when it was late at night. Two of the interviewees (respondent 93, female, 28; respondent 94, female, 21) gave birth during the lockdown. Respondent 93 said that she was not allowed to take her mask off during labour. Respondent 94 said that it was scary to give birth in a hospital during the lockdown, as it was full of sick people. She feared for her baby's life and did not allow friends to touch her baby. Respondent 104 (male, 27) had an internship, but lost it due to the lockdown.

However, some respondents overcame adversity by managing to find "piece jobs" (Respondent 143, nap), survive on the government relief fund and UIF, and start online businesses (Respondent 144, nap). Business owners obtained assistance from the government relief fund and unemployed individuals like Respondents 124 (male, 26) 156 (female, 25) managed to become employed through the Public Works Youth Brigade Program. Essential public workers like Respondent 157 (male) did not suffer a financial toll. Respondent 162 (male, 27), a business owner uncertain about the future of his business, used the opportunity to study and get a job. Respondent 167 (male, 30) was fortunate in that his business was not affected due to his specialization in online retail. Respondent 16 (male 27) said that it was good to do shopping online and to do things from home. He also liked that he could do Skype interviews. Respondent 29 (male, 56) said that he was able to work from home and received his salary as usual, whereas respondent 74 (male, 23), an essential worker, was happy that he could drive freely, as there was not a lot of traffic. Respondent 87 (female, nap) even managed to find a position as a security guard during the lockdown. One woman (Respondent 111, 50) was part of an organization that teaches women business skills. She did not complete the course due to the lockdown, but she was happy about this, as this meant that she would receive support for longer. She said that, despite the lockdown, people still bought clothes and chickens, which she 
van der Spuy, A. \& Jayakrishnan, L. Making Sense of the Unknown:

A Narrative Analysis of COVID-19 Stories as Told by WSU Research Students

was selling. She also sold in small villages, because she said these were often neglected by sellers. Respondent 110 (female, 58) said that they were very busy, as she ran a funeral parlor. She said they had many deaths, but it was bitter, as these people were her friends and family.

\section{Student Life}

Of particular interest to us as lecturers, were the comments in the sub-category "student life". The common pandemic stressor among students and teachers was the loss of the academic year and the shift in pedagogy to emergency remote teaching. They worried about returning to school and contracting the virus. Educators were tasked with monitoring students as they entered school premises, taking their temperature, ensuring social distancing in the classrooms and outside. Respondent 155 expounded on how teaching time was increased due to classes being divided into smaller groups. Peer learning could not be used, and they had to entrust students with marking their own papers. A constant worry was the lack of training in online learning and misuse of learning instruments by the students who used it as a social media tool. The academic calendar was constantly disrupted due to students or staff contracting COVID19 , which would necessitate the closing and fumigation of the school and for contact cases to go into quarantine. In the case of school hostels, students would have to be fetched by their parents. The return to schools, therefore, proved to be a costly exercise.

Many students found the online learning experience challenging. Respondent 34 (male, 27) said online classes were difficult, as he needed more data. Respondent 40 (female, nap) described her experience as overwhelming, while respondent 41 (female, nap) said that it was unfamiliar. Another student (Respondent 44, male, 22) indicated that online learning was difficult, due to him being unable to afford enough data. Respondent 45 (female, 27) also said that it was challenging, because of a lack of support and a lack of discipline. A nineteen-yearold school learner (respondent 55, male, 19) had no experience with computers and found the learning difficult, as he first had to learn how to use the technology.

Much of the struggle experienced by students, had to do with the internet reception in the rural areas. Respondent 17 (female, 30) explained that the network coverage in her area was bad and that she missed classes and deadline because of this. Respondent 38 (female, 22) came from a rural area. She said it was very difficult to study, due to the poor network in their area. Respondent 78 (male, 22) also mentioned the network issues in the rural areas of the province, as did respondent 102 (female, 25).

Some spoke about privacy issues at home, or the noise levels and overcrowding that made studying difficult. Respondent 3 (female, 16) lived in a small house with no privacy for studying or online learning. Respondent 15 (female, nap) said that she had many siblings at home and were distracted, whereas respondent 38 (female, 22) stated that she was from a big family which created a lot of noise. Added to this, they also had to deal with responsibilities at home, such as household chores. Respondent 68 (female, 23) said that she had to balance house work and learning, and that her siblings thought she was lazy and hiding behind school work. This all added to the already challenging situation that they were in.

Another major topic was that they were unable to interact with classmates and lecturers (respondent 3, female, 16). According to the respondents it was difficult to understand the work without a teacher or lecturer physically present to explain (respondent 15, female, nap; 
respondent 44, male, 22; respondent 45, female, 27; respondent 53, female, 21; respondent 91 , male, 24). Respondent 44 specifically said that he needed one-on-one interaction with the lecturers. Respondents 159 and 164 (both female, nap) revealed how much they missed traditional learning, interactions with their classmates and group study sessions where they could obtain academic support from their peers and revisit challenging tasks.

Final year students explained that they needed to do in-service-training of six months in order to complete their diploma. However, they found it difficult to obtain a trainee position due to the lockdown (respondent 17, female, 30; respondent 66, female, 23). Some were on the verge of graduation but found their career plans ruined due to the lengthy academic year with few job prospects, and having to stay at home due to the pandemic. They revealed their worry over repeating the year due to lack of knowledge and digital skills and called the year "the survival of the fittest". Respondent 165 (female, nap), a Health Sciences student, expounded on her inability to complete the practical component in hospitals as staff were focused on COVID-19 patients.

Most students expressed their inability to cope with online learning due to network connectivity and data issues, the challenge of listening to lectures over electronic devices, not being added onto their course modules on Microsoft Teams, and their frustrations with the lack of assistance and patience from their lecturers. They referred to online learning as a "nightmare", especially at WSU, where it made a late advent. Since the majority of WSU students come from rural areas, they experienced the challenges of being at home as opposed to the university residences where they could access free Wi-Fi. Due to bad network, they would have to wait till midnight for the signal to be strong so that they could study. Another reason for late study sessions would be due to the noisy household as the entire family was together. They found the rural environment not conducive to studying as their parents could not understand the value of education and expected assistance with domestic chores. They also incurred financial costs in purchasing data.

Three high school learners (respondents 119, 139 and 163, nap) were anxious about adjusting to online learning, the loss of study time during the lockdown, not going to school, how the lockdown took away the elements of school life, how difficult it was to study without meeting teachers regularly and fearing for their future. Even when they returned to school during Level 3 , they worried about contracting the virus and found it difficult to comprehend what the teacher was saying through the mask. They were concerned about studying under pressure with no time to prepare for exams and revealed how they were expected to submit tasks with little preparation. Respondent 139 (female, nap) who is a Grade 11 learner did not feel prepared for the matric year due to the short academic year and called it a "difficult year". She found the year traumatic due to the loss of some teachers and just wanted the year to be over.

The students were grateful for the time spent with family and especially in being beneficiaries of the NSFAS allowance. This enabled them to receive free laptops, use the allowance for the purchase of data and in some cases, even assisted their families in buying groceries and other critical essentials. Respondent 23 (female, 21, nap) said that she loved staying at home and that the e-learning assisted her. Respondent 80 (male, 21, nap) said the laptops and data that the university had provided, made life easier. 
van der Spuy, A. \& Jayakrishnan, L. Making Sense of the Unknown:

A Narrative Analysis of COVID-19 Stories as Told by WSU Research Students

\section{Discussion}

The study was an exploration of the pandemic experience in the Eastern Cape. The positive and negative impact of the pandemic as well as people's lived experiences, their challenges, issues faced, coping mechanisms and successes were investigated. The study was conducted during the 2020 academic year during lockdown and adds to current literature by providing the experiences and challenges faced by people in the Eastern Cape, South Africa, during the pandemic.

It is clear from the above findings that the lockdown in the Eastern Cape Province of South Africa, hit the people of the province very hard. The lockdown affected them mostly negatively, with very few positives coming from the experience. However, it is clear that those with fixed employment were better off than those with part-time work, "side hustles" or "piece jobs". Only two people said that they were entirely unaffected by the lockdown, except for having to wear a mask (respondent 61, male, 61; respondent 83, male, 59). Both of them were unemployed and were living off the government social grants. According to them, they did not have to travel, as they were not looking for work. Their lives basically stayed the same.

\section{Conclusion}

The study found that most participants experienced an elevated level of stress and trauma due to issues and challenges connected with their families, job, and education. Of particular importance to us as lecturers was the stress that the pedagogical shift to emergency remote teaching brought. The shift wrought an upheaval to both the staff and students of the historically disadvantaged and poorly resourced schools and universities of the Eastern Cape. Academics and students were in a "sink or swim situation" which some respondents referred to as a "nightmare" and "survival of the fittest." Students had to regulate their own learning in a province where digital transformation and connectivity was poor, and consequently felt isolated in every aspect of their lives. Academics had to make the switch from traditional learning to emergency remote teaching with a significant lack of training and tools, in a brief time. These stories present a picture of stress, trauma, and the endurance of the human spirit.

\section{References}

Barnouw, E., Gerbner, G., Schramm, W., Worth, T., \& Gross, L. (1989). International Encyclopedia of Communication (Vol. 1). New York, NY: Oxford University Press.

Carrillo, C., \& Flores, M. A. (2020). COVID-19 and teacher education: a literature review of online teaching and learning practices. European Journal of Teacher Education, 43(4), 466-487. https://doi.org/10.1080/02619768.2020.1821184

Clandinin, D. J. (2006). Narrative inquiry: a Methodology for studying lived experience. Research Studies in Music Education, 27, 44-54.

Clandinin, D. J. (2013). Engaging in Narrative Inquiry. London and New York: Routledge.

Clandinin, D. J., \& Michael, C. F. (2000). Narrative Inquiry: Experience and Story in Qualitative Research. San Francisco: Jossey-Bass.

Clandinin, D., Cave, M., \& Berendonk, C. (2017). Narrative inquiry: a relational research methodology for medical education. Medical Education, 51(1). Retrieved June 10, 2021, from http://0- 
web.b.ebscohost.com.wam.seals.ac.za/ehost/detail/detail?vid=4\&sid=4aac6b32e12e-41e6-8604-161f2d1e6c44\%40pdc-vsessmgr02\&bdata=JnNpdGU9ZWhvc3QtbG|2ZQ\%3d\%3d\#db=a9h\&AN=120262940

Connelly, F. M., \& Clandinin, D. J. (1990). Stories of experience and narrative inquiry. Educational Researcher, 19(5), 2-14.

Gilstein, J. (2020). Narrative Inquiry. Retrieved May 16, 2021, from Salem Press Encyclopedia: http://0-

eds.b.ebscohost.com.wam.seals.ac.za/eds/detail/detail?vid=0\&sid=7ee80570-e4d84189-a77a-f101e16ab30f\%40pdc-vsessmgr02\&bdata=JnNpdGU9ZWRzLWxpdmU\%3d\#AN=90558399\&db=ers

Hsieh, H., \& Shannon, S. (2005). Three approaches to qualitative content analysis. Qualitative Health Research, 15(9), 1277-1288.

Krippendorff, K. (1989). Content analysis. In E. Barnouw, G. Gerbner, W. Schramm, T. Worth, \& L. Gross, International Encyclopedia of Communication (Vol. 1, pp. 403-407). New York, NY: Oxford University Press. Retrieved June 10, 2021, from http://repository.edu/asc_papers/226

Mpungose, C. B. (2020). Emergent transition from face-to-face to online learning in a South African University in the context of the Coronavirus pandemic. Humanities and Social Sciences Communications, 7(1), 1-9. https://doi.org/10.1057/s41599-020-00603-x

National Institute for Communicable Diseases. (2020, March 5). First Case of COVID-19 Coronavirus Reported in South Africa. Retrieved June 9, 2021, from National Institute for Communicable Diseases: https://www.nicd.ac.za/first-case-of-COVID-19coronavirus-reported-in-sa/

South African News Agency. (2020, March 23). President Ramaphosa Announces a Nationwide Lockdown. Retrieved June 9, 2021, from South African News Agency:

https://www.sanews.gov.za/south-africa/president-ramaphosa-announcesnationwide-lockdown

Stemler, S. (2000). An overview of content analysis. Practical Assessment, Research and Evaluation, 7(Article 17), 1-6. Retrieved June 10, 2021, from https://scholarworks.umass.edu/cgi/viewcontent.cgi?article=1100\&context=pare

Tarman, B. (2020). Editorial: reflecting in the shade of pandemic. Research in Social Sciences and Technology, 6(1), i-iv. Retrieved July 14, 2021, from https://ressat.org/index.php/ressat/article/view/476/88

Williams, T., McIntosh, R., \& Russell, W. (2021). Equity in distance education during COVID-19. Research in Social Sciences and Technology, 6(1), 1-24. Retrieved June 9, 2021, from https://ressat.org/index.php/ressat/article/view/524/94

Wimpenny, K., Beelen, J., \& King, V. (2020). Academic development to support the internationalization of the curriculum (IOC): a qualitative research synthesis. International Journal for Academic Development, 25(3), 218-231. https://doi.org/10.1080/1360144X.2019.1691559 